\title{
TWO PROBLEMS IN ANCIENT MEDICAL COMMENTARIES
}

\section{AN ANONYMOUS COMMENTARY ON HIPPOCRATES' APHORISMS}

Thirty years ago, H. Flashar discussed the introduction to an anonymous commentary on the Aphorisms of Hippocrates. ${ }^{1}$ The text contains an interesting picture of Hippocrates as a culture hero, who saved suffering humanity by the introduction of systematic medicine. The first section of this introduction offers some complicated problems. It ends with an extremely long and difficult sentence, which has not yet been explained quite satisfactorily, and it contains a curious use of the verb $\sigma a \rho \kappa o ́ \omega$, combined with $\tau \dot{\eta} \nu \phi v ́ \sigma \iota$, which has led Flashar to suspect Christian influence. These two points are the subject of the first part of this paper.

The text as printed by Flashar runs thus:

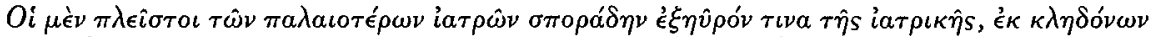

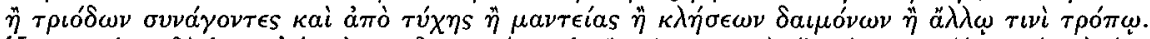

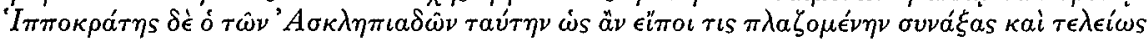

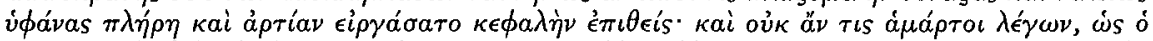

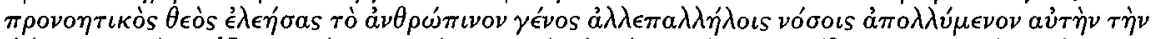

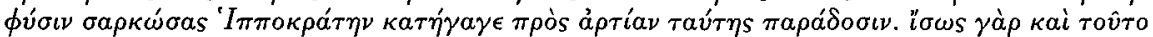

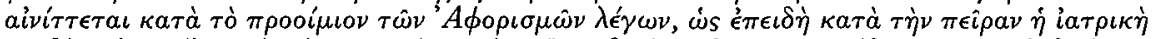

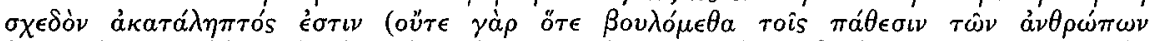

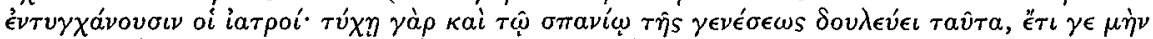

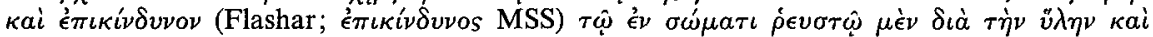

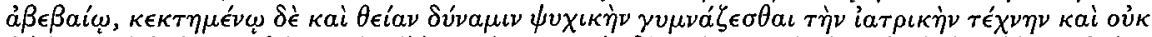

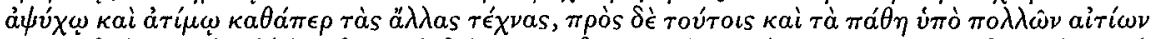

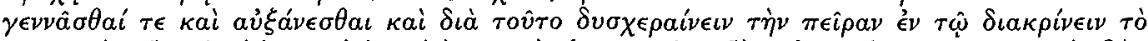

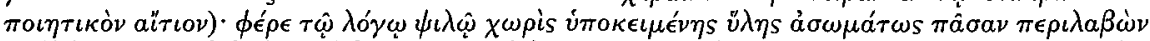

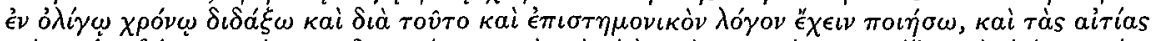

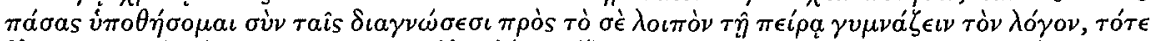

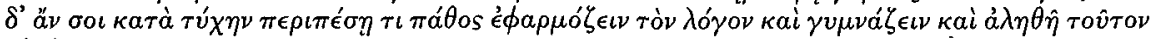

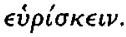

If I understand Flashar (op. cit. p. 405 n. 2) correctly, he takes the last long sentence as a paraphrase of Hipp. Aph. 1.1: $\dot{\eta} \delta \epsilon \pi \epsilon \hat{\imath} \rho \alpha \sigma \phi a \lambda \epsilon \rho \dot{\eta}^{\prime}, \dot{\eta} \delta \dot{\epsilon} \kappa \rho \dot{i} \sigma \iota s \chi \alpha \lambda \epsilon \pi \eta^{\prime}$. Reading

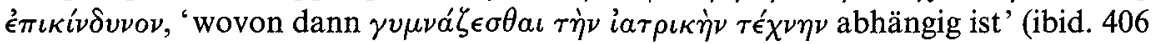

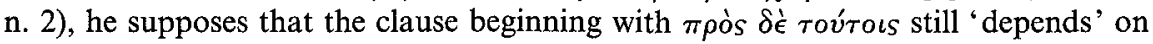
it, but in a very loosely construed way. He states that Hippocrates cannot be the subject of the last part of the sentence, because the intervening infinitives would point to an indirect construction, while the first person singular would mean a reversion to direct speech.

${ }^{1}$ H. Flashar, 'Beiträge zur spätantiken Hippokratesdeutung', Hermes 90 (1962), 402-18. The text may be found as well in F. R. Dietz, Scholia in Hippocratem et Galenum II 244f. For further references, see Flashar, op. cit. pp. 402ff. I would like to thank Professor Dirk M. Schenkeveld and the anonymous reader of $C Q$ for their helpful criticism on an earlier draft of this paper. Research for this paper was made possible by a fellowship of the Royal Dutch Academy of Arts and Sciences. 
I would suggest a different solution: $\lambda \epsilon^{\prime} \gamma \omega \nu$ is is picked up, after a very long interruption, by $\phi \epsilon^{\prime} \rho \epsilon \ldots \delta \iota \alpha^{\prime} \xi \omega \kappa \tau \lambda$., $\dot{\omega} s$ functioning as a colon (as often) and being left untranslated; Hippocrates is without doubt the subject of $\delta \iota \delta a ́ \xi \omega$. The $\epsilon \pi \epsilon \iota \delta \eta^{\prime}$

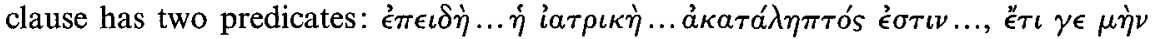

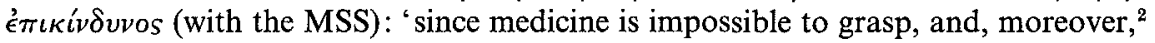

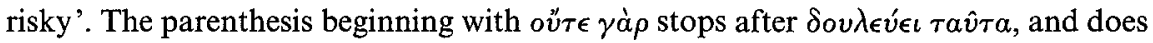
not continue until ait part $\tau \hat{\omega} \dot{\epsilon} v \sigma \dot{\omega} \mu \alpha \tau \iota \kappa \tau \lambda .: \tau \hat{\varphi}$ does not go with a (substantival) adjective $\dot{\rho} \epsilon v \sigma \tau \hat{\varphi}$, as Flashar takes it, but it should be construed with the infinitive $\gamma \nu \mu \nu \alpha \zeta_{\epsilon \sigma} \sigma a \iota$ (and -

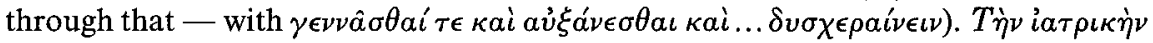
$\tau \dot{\epsilon} \chi \nu \eta \nu$ functions as a subject accusative with $\gamma \nu \mu \nu a ́ \zeta \epsilon \sigma \theta \alpha$. The construction $\tau \hat{\omega} \ldots \gamma v \mu \nu \alpha^{\prime} \zeta \epsilon \sigma \theta \alpha \iota$ is difficult because of the many constituents intervening between the article and its 'noun', the infinitive. However, in the very same passage we have an undisputed parallel for this construction: the final part of the sentence contains the substantival infinitives (or rather accusative-and-infinitive-constructions) ( $\pi \rho \dot{s} s$ ) $\underline{\tau o ̀} \sigma \grave{\epsilon} \ldots \gamma v \mu \nu a ́ \zeta \epsilon \iota \nu, \tau o ́ \tau \epsilon \delta^{\prime} \ldots \dot{\epsilon} \phi a \rho \mu o ́ \zeta \epsilon \iota \nu$, where $\tau o$ goes with both infinitives. Here, too, there is a remarkably large number of constituents intervening between the article and the infinitive; perhaps we should consider reading o̊ $\tau \epsilon \delta^{\prime} \not ̈ \nu$ instead of $\tau o^{\prime} \tau \epsilon$ $\delta$ ă (so Dietz).

The translation of the last sentence might run: 'For maybe he makes an allusion to this, too, in the prooemium of the Aphorisms, saying: "Since medicine is practically impossible to grasp by means of experience (for doctors do not encounter diseases in people when we wish to ${ }^{3}$ for that depends on chance and the rarity of its appearance) and [since medicine is] moreover risky in that medicine is practised on a body, (which is on the one hand in a state of flux and unstable because of its material, but on the other hand possesses a divine spiritual power), and not on something lifeless and worthless, like the other technai, and further [it is risky] in that diseases originate and grow from many causes and therefore experience has trouble in distinguishing the causa efficiens: come on, let me grasp it purely theoretically, without underlying material, bodilessly, and explain it briefly; thereby I shall bring about that medicine has a basis of theory and I shall suggest all the various causes with the diagnoses, in order that you may henceforth train your theoretical knowledge with experience and that you may adapt your theory, whenever you meet a case of disease, and exercise it and find it true.",

It is interesting to notice the many parallels between this short explanatory paraphrase of Hippocrates' prooemium and Galen's commentary on the same passage (XVII 2, 345-56 Kühn). These parallels make it likely that our text is meant as a commentary on the whole first chapter of Aphorisms. As Galen explicitly tells us, ancient exegetes were agreed that this whole chapter was meant as the prooemium (op. cit. $346 \mathrm{~K}$.).

Like our commentator, Galen, too, points out that $\dot{\eta} \pi \epsilon \hat{\imath} \rho \alpha \sigma \phi \alpha \lambda \epsilon \rho a$ holds good ' $\delta \iota \dot{\alpha} \tau o ̀ ~ \tau \hat{\eta} s \ddot{v} \lambda \eta s \dot{\alpha} \xi i \omega \mu \alpha$ ', because of the value of the material. And on p. 353 it is

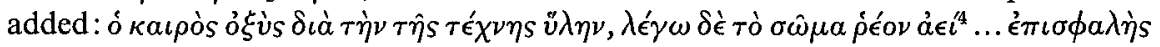
$\delta \dot{\epsilon} \dot{\eta} \pi \epsilon \hat{\imath} \rho \alpha \kappa \alpha i \alpha \dot{v} \tau \dot{\eta} \delta \dot{\alpha} \tau \dot{\eta} \nu \ddot{v} \lambda \eta \nu$, and then Galen adds precisely the difference with the other technai noted in our commentary: they practise safely on lifeless material.

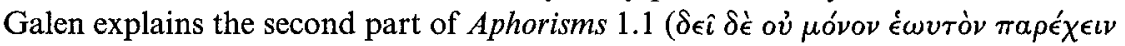

${ }^{2}$ For the combination $\gamma \epsilon \mu \eta \dot{v}$, see J. D. Denniston, The Greek Particles (Oxford, 1959), p. 349. ${ }^{3}$ "O $O_{\tau \epsilon} \beta o v \lambda{ }^{\prime} \mu \epsilon \theta a$ is, of course, unremarkable in Greek of this date.

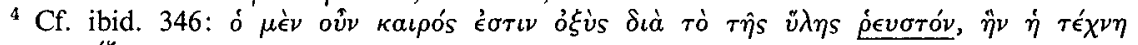
$\mu \in \tau a \chi \in \iota \rho i \zeta \in \tau a \iota$. 


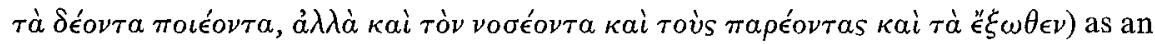

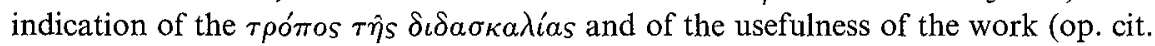
$351 \mathrm{~K}$.). He points out (ibid. 352) that aphorisms are the best way to teach and learn a lot in a short compass, which in turn is necessitated by the shortness of life - all this is also expressed in the $\phi \epsilon \in \epsilon$-clause of our commentary.

Thus, by means of this paraphrase our commentator has put quite an extended version of Aphorisms 1.1 in the mouth of Hippocrates: a whole programme of medical teaching is hidden in its few words. The actual wording of Aphorisms 1.1 is no more than an allusion (aivi $\tau \tau \epsilon \tau \alpha \iota)$ to the task imposed on Hippocrates by the provident god and fully accepted by Hippocrates himself: to provide accurate reports of the art

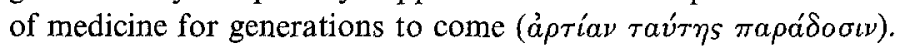

Let us now turn to the other problem of our passage. Flashar rightly calls attention

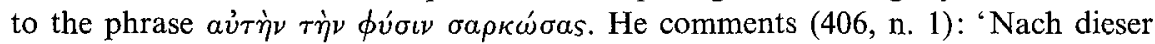
eigenartigen Formulierung ist... nicht daran gedacht, dass der vorhersehende Gott seine eigene Natur, sondern die Natur selbst in Hippokrates menschliche Gestalt annehmen lässt. Dies lässt sich wohl nur im Sinne der stoischen Lehre verstehen ... Der Begriff der Fleischwerdung ist hier ohne den Einfluss christlicher Lehren schwer vorstellbar, dann aber zeugt der Gedanke von einer schon sehr weitgehenden Vermischung stoisch-christlicher Weltanschauung.' Flashar thinks the sentence betrays Christian influence and possibly indicates Christian authorship. This suggestion has so far gone unchallenged. O. Temkin, in his recent Hippocrates in a World of Pagans and Christians, gives his explicit support to Flashar. ${ }^{5}$ Temkin translates: 'and nobody is likely to err who says that the provident god, taking pity on mankind, which was being destroyed by successive diseases, made nature herself into flesh and led Hippocrates to the perfect transmission of this [art]' (op. cit. 46).

I do not, however, feel so confident about the Christian influence, even when taking into account a point Temkin seems to allude to, viz. the difference between incarnation of the $\phi v o \iota s$ and that of the Aóyos. Although it may be hard to imagine the concept of $\sigma a ́ \rho \kappa \omega \sigma \iota s$ outside a Christian context, it seems even harder to imagine it within such a context, but applied to Hippocrates.

A second problem is the reference of $\tau a v i \eta \eta s$. All agree that this should be the art

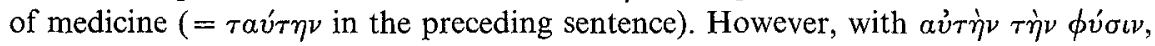

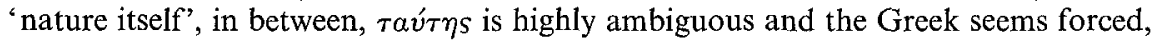
as appears from Temkin's translation.

A definite solution I cannot offer. One might attempt to evade the problem of the representation of Hippocrates as Christ and to render $\tau a u ́ \tau \eta s$ unambiguous by

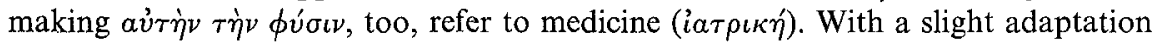
of Temkin's rendering this would yield: '...the provident god... made the very essence (sc. of medicine) into flesh ... ${ }^{6}$ and led Hippocrates to its perfect transmission.' In this interpretation, Hippocrates is regarded as medicine incarnate and takes on the

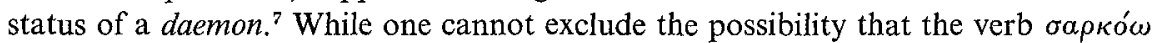

5 Baltimore-London, 1991, 46; 251.

${ }^{6}$ Perhaps this necessitates reading aư $\hat{\eta} s$ (= ipsius) rather than $a \dot{v} \tau \eta^{\prime} v$, bearing in mind that

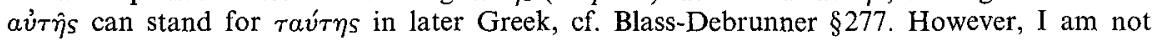
convinced that this is necessary. For ov́ous 'essence', see Lampe s.v. II A.

$7 \mathrm{Cf}$. for daemones/heroes helping mankind, because a supreme god took pity, Maximus of Tyrus, Dissert. XV 6: Souls that are freed from their bodies take pity on other souls

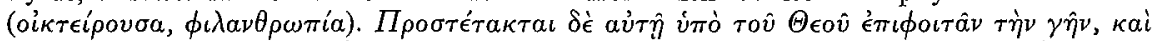

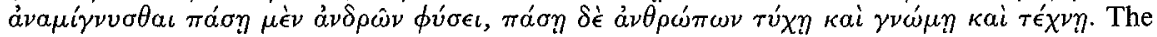
daemones show a preference for the occupation they had when they were still human. Thus, Asclepius takes care of medicine. For other parallels see the commentary on Posidon. Fr, 108 by Edelstein and Kidd. 
betrays Christian influence, there is no need to assume an application that would surely be blasphemous in Christian eyes. ${ }^{8}$

\section{JOHN OF ALEXANDRIA ON THE USE OF PREPOSITIONS}

In a recent article Vivian Nutton comments on the complicated tradition of a commentary on Galen's On Sects for Beginners, ascribed to John of Alexandria (7th cent. A.D.). ${ }^{9}$ Nutton explains (op. cit. 510f.) that in fact we have to take into account three different texts: the Latin translation of John's commentary, ascribed to Burgundio of Pisa; another Latin version of a commentary on Galen, on the name of Agnellus of Ravenna. This is closely related to 'John' (as the first translation will henceforth be called). This commentary, too, goes back to a Greek original. And, thirdly, a Greek commentary on Galen's On Sects, ascribed to Archelaus. This commentary bears signs of being closely linked to parts of Agnellus' Latin version. The Greek 'John' is lost. Probably all three texts are either translations or adaptations of John's commentary, but it cannot be excluded that the similarities are accidental in so far as they are due to the fact that all three texts contain a typical commentary-discourse, provoked by the same source-text. On balance, Nutton rejects this latter possibility for the relationship between John and Agnellus: they are thought to be versions of the same Greek text.

On p. 517 Nutton discusses the commentaries on the second sentence of Galen's

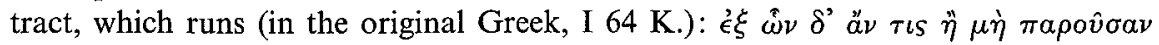

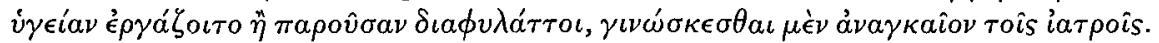
In Latin, this sentence is translated as follows (19,28ff. Pritchet): ex quibus autem quis vel non presentem sanitatem operetur vel presentem custodiat, noscendum quidem necessarium medicis. As Nutton has seen, the commentaries notice that Galen seems to use the expression for a material cause ( $\dot{v} \lambda \iota \kappa o$, , materialis), instead of the expected

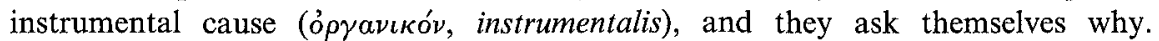
According to Nutton, neither John's nor Agnellus' answer makes sense. Their comments run as follows:

John 22, 18-20 Pritchet: Et quidam opponunt Galieno dicentes 'Quare dixit ex quibus et non "quali organo"?' dicimus quod hec prothesis accipitur: sic enim in figuris grammaticorum (infantes grammaticorum $\mathrm{MSS}^{10}$ ).

Agnellus 40, 19-21: hic prothesis prothes accipit: sic enim infantes grammaticorum dicent, pro $T$ ponent $D$.

Archelaus' version provides a first key to the solution:

${ }^{8}$ Formerly, I entertained the possibility that $\sigma \alpha \rho \kappa o ́ \omega$ was used in its medical sense here, i.e. meaning 'to make fleshy or strong' (LSJ, s.v.). The word and its derivatives (like $\sigma \alpha$ ' $\rho \kappa \omega \sigma \iota s$ or $\sigma a \rho \kappa \omega \tau \iota \kappa o ́ s)$ are very frequent in all medical writers. For a link with $\phi v \sigma_{\iota s}, \mathrm{cf}$. Gal. X $178 \mathrm{~K}$.

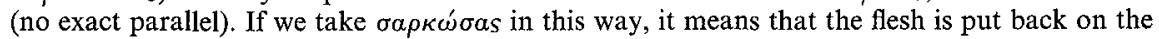
bones of emacerated humanity. The provident god himself is the superior doctor who applies

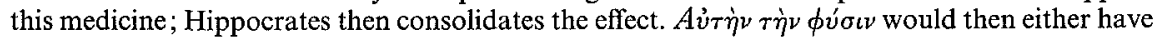
to refer to an abstract 'nature itself', or - perhaps more probably - to the constitution of humanity. In that case one might translate: 'the provident god ... gave nature itself a fleshy strength and sent down Hippocrates etc.' However, on balance this solution seems less attractive.

9 V. Nutton, 'John of Alexandria again: Greek Medical Philosophy in Latin Translation', $C Q 41$ (1991), 509-19. The article itself is a reaction to an earlier article by $\mathbf{R}$. J. Hankinson, 'Notes on the Text of John of Alexandria', CQ 40 (1990), 585-91. References to John's commentary are based on the edition by C. D. Pritchet, Iohannis Alexandrini Commentaria in librum De sectis Galeni, Leiden, 1982. For further references, see Nutton, op. cit., esp. notes 9 and 10.

${ }^{10} C Q$ 's anonymous referee informs me that in figuris does not appear in any manuscript, but is an emendation of the second printed edition. 


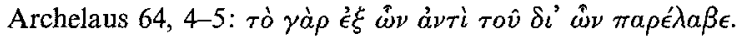

'The original question must... have focused on Galen's choice of one Greek preposition over another' (op. cit. 517), and, I may add, the answer will duly have dealt with this. Obviously, this brought John into difficulties. His translation quali organo correctly indicates the different type of cause involved, but it obscures the fact that the cause required is usually expressed by a different preposition. Agnellus' translation seems to have adhered closer to the Greek. Therefore, Nutton claims (rightly, I think) that the problems in John are due to mistranslation from the Greek, while those in Agnellus should be considered corruptions in the transmission of the Latin version (op. cit. 517).

I do not agree with Nutton, however, in his evaluation of the appeal to the grammarians. According to him, the comment found in Agnellus tries to defend Galen by criticizing 'grammarians' slovenly habits'. But, he adds, in the rest of the commentary (both in John's and Agnellus' versions) the role played by grammarians is generally a positive one. He considers this problematic; in fact, we shall see that this problem is based on a misunderstanding.

All in all, Nutton believes that the grammatical remark was indeed part of the Greek original (p. 518); he thinks John's text (with the reading of the MSS infantes) is in order; the Latin translates the Greek periphrastic $\pi \alpha \hat{\imath} \delta \in s \quad \gamma \rho \alpha \mu \mu \alpha \tau \iota \kappa \hat{\omega} \nu$, for $\gamma \rho а \mu \mu a \tau \iota k o \imath)$. The incoherence is the translator's fault. Agnellus he emends as follows: hic prothesis [prothes] accipitur: sic enim et infantes grammaticorum dicent, pro EX ponent $D I A-$ "Here the preposition is used (is acceptable?), for, the grammarians say, they will put $\dot{\epsilon} \xi$ instead of $\delta \iota \alpha$ '.

The problem with this emendation is the unpleasant stress on the fact that a preposition is used (and not another part of speech?). To my mind, all versions of the commentary try to defend Galen's text by appealing to a rule which the grammarians had deduced from their literary experience. The commentaries definitely do not appeal to sloppy Greek or Latin supposedly used by the grammarians themselves that would be an intrinsically weak argument. The only possibility open to the commentators is, of course, to refer to a usage which is established as correct Greek or Latin by the grammarians in their role of guardians of linguistic correctness - and in fact that is exactly what they are doing. For in both Greek and Roman grammar the phenomenon of one preposition being used instead of another is well known, and although it is regularly mentioned among the causes of solecism, many instances from respected and authoritative older writers are quoted only to be explained by the rule of hand ' $\pi \rho \theta^{\prime} \theta \epsilon \sigma \iota s$ d่ $\nu \tau i$ i $\pi \rho \circ \theta \epsilon ́ \sigma \epsilon \omega s$ ', or 'praepositio pro praepositione'. Some examples must suffice:

Greek examples:

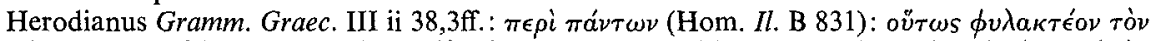

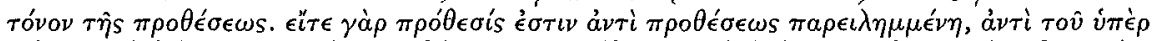

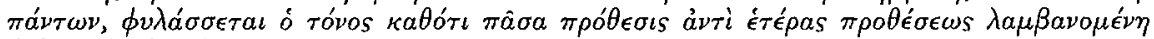

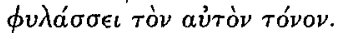

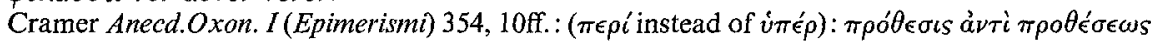

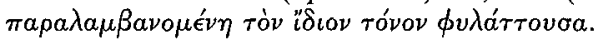

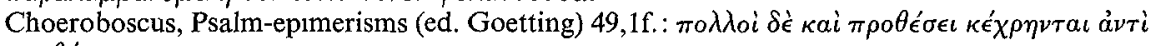
$\pi \rho \circ \theta \epsilon ́ \sigma \epsilon \omega s$.

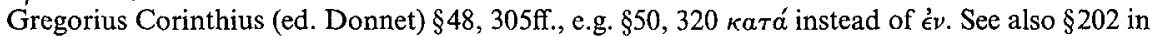
the context of barbarisms/solecisms.

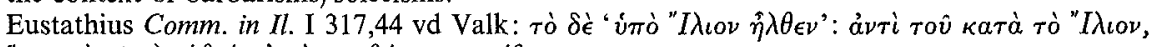

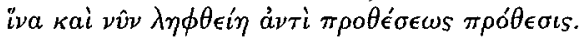

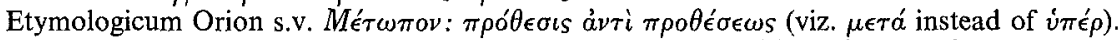

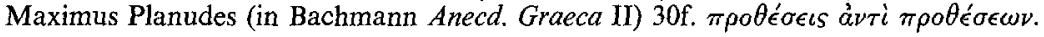


A similar view of the respective roles of $\epsilon^{\prime} \kappa$ and $\delta \iota \alpha$ is provided by Plutarch,

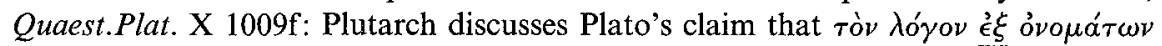
$\kappa \alpha i \dot{\rho} \eta \mu a ́ \tau \omega \nu \kappa \epsilon \rho a ́ v \nu v \sigma \theta \alpha$. In so saying, Plato did not necessarily forget about the other parts of speech. For in that case he would have used the wrong preposition: ov

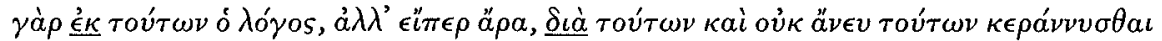
$\pi \dot{\phi} \phi v \kappa \epsilon \nu$.

Latin grammarians, too, are perfectly familiar with this phenomenon: ${ }^{11}$ they consider the interchange of prepositions as one of the causes of solecism as early as Quintilian 1.5.51, see e.g. Donatus (Gramm. Lat. IV 394, 16) (soloecismus per praepositionem) cum alia pro alia ponitur aut necessaria subtrahitur. ${ }^{12}$ But the same usage also occurs (and is perfectly acceptable) in the auctores. In Quintilian (9.3.2) this kind of figures of speech form a specific type, called the genus grammaticum (as opposed to the genus rhetoricum). His point is that there is an exact correspondence between these figures of speech and the vitia sermonis. ${ }^{13}$ Servius often calls attention to such cases, as e.g. on Verg. Ecl. I 15: conixa pro eo quod est enixa: nam hiatus causa mutavit praepositionem. Here, the art of the poet has avoided hiatus by substituting one preposition for another. ${ }^{14}$ In his commentary on Verg. $A$. II 52 Servius even uses the formulaic praepositio pro praepositione. ${ }^{15}$

The form of the rule just asks for accidents of transmission: Pompeius (Gramm. Lat. V 268) shows what may happen quite clearly: nam invenimus praepositionem >pro praepositione om. $\mathrm{ABC}>$ positam e.q.s. It would seem that at least Agnellus has suffered somewhat along the same lines. This was facilitated even more by the use of the Greek word prothesis in a Latin context, yielding a perfect homoearcton, three consecutive words beginning with pro.

Archelaus does not give any problems whatsoever. He states quite clearly what happened, viz. that one preposition group was exchanged for another. Agnellus has preserved clear traces of the same intention. With some minor changes his text yields (Agnellus 40, 19-21): hic prothesis $\langle$ pro $\rangle$ prothes $\langle i\rangle$ accipit $\langle u r\rangle:$ sic enim infantes grammaticorum dicent, pro EX ponent DIA ("Here one preposition is used instead of another: for this is what the grammarians will say, they [i.e. 'auctores'] will use EX instead of DIA.')

John's text, reading infantes, derives from the same Greek model as Agnellus. Hec is the last trace of the fact that the original context opposed two different prepositions to each other: hec prothesis accipitur: sic enim infantes grammaticorum ("The use of) this preposition is acceptable: thus the grammarians [say].')

One might envisage something like the following as the Greek original: $\Pi \rho{ }^{\prime} \theta \epsilon \sigma \iota s$

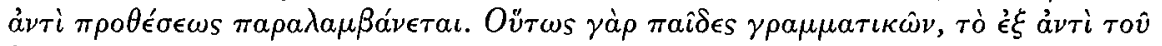
$\delta \iota \dot{\text {. }}$

11 E.g. Prisc. Gramm. Lat. III 294, 5; 302, 25ff.; 371, 7f.

12 Cf. ibid. 393, $21 \mathrm{ff}$; Charisius 268, 29 Barwick; Sergius Explan. in Don., Gramm Lat. IV 564, 14f.; Marius Plotius Sacerdos, Gramm. Lat. VI 450, 17ff.; Isıd. Etym. I 33, 4.

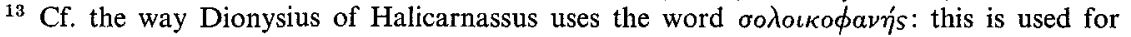
locutions that might seem to be faulty but for the authority of the writer who uses them: see e.g. DH Thuc. 29; 55; Serv. in Verg. A. 4. 355.

14 Notice that according to ancient theory the fact that we are dealing with a prepositional prefix here, is irrelevant. Prepositions can occur single and in compounds per defintionem.

${ }_{15}$ See further Serv. on Verg. E. 8.66; G. 4.144; A. 2.2, 52; 3.446; 9.193. Augustine points out that prepositions can be 'translated' by other prepositions, de Mag. II 4 (about Verg. $A$. 2.659): praepositıo est ex pro qua de possumus, ut arbitror, dicere. 